\title{
KONDISI TERUMBU KARANG PADA KAWASAN WISATA PANTAI MALALAYANG KOTA MANADO PROVINSI SULAWESI UTARA DENGAN MENGGUNAKAN METODE UNDERWATER PHOTO TRANSECT
}

\author{
(CONDITION OF CORAL REEFS USING THE UNDERWATER PHOTO TRANSECT METHOD IN \\ MALALAYANG BEACH TOURISM AREA, MANADO CITY, PROVINCE NORTH SULAWESI PROVINCE) \\ Devidson Daud $^{1 \star}$, Joshian N. W. Schaduw ${ }^{1}$, Chatrien Annita Luzianna Sinjal ${ }^{1}$, Janny D. \\ Kusen $^{1}$, Erli Y. Kaligis ${ }^{1}$, Adnan S. Wantasen ${ }^{2}$
}

1. Program Studi IImu Kelautan, Fakultas Perikanan dan IImu Kelautan, Universitas Sam Ratulangi, Manado. 95115, Sulawesi Utara, Indonesia.

2. Program Studi Manajemen Sumberdaya Perairan, Fakultas Perikanan dan IImu Kelautan, Universitas Sam Ratulangi, Manado. 95115, Sulawesi Utara, Indonesia.

*email: daviddaud100@gmail.com

\section{ABSTRACT}

Coral reefs are coastal ecosystems with the highest level of diversity with around one million species worldwide. Corals are invertebrates belonging to the Phylum Coelenterate (hollow animals) or Cnidaria. The Underwater Photo Transect (UPT) method is a method that utilizes technological developments, both digital camera technology and computer software technology. Capturing data in the field in the form of underwater photos carried out by shooting using a Canon G-16 camera equipped with a waterproof protector (housing). In this study it can be seen that the percentage of hard corals at point 1 is in the medium category, point 2 is in the medium category, and point 3 is in the bad category with the percentage of hard coral cover as follows: point 1 (one) 29.75\%, point 2 (two) $31.16 \%$, and point 3 (three) $24.26 \%$, of the three points can represent the overall condition of the coral reefs in Malalayang Beach which is in moderate condition with a percentage of $28.39 \%$.

Keywords: Malalayang Beach, Coral Reef, UPT, CPCe

Terumbu karang merupakan ekosistem pesisir dengan tingkat keanekaragaman tertinggi dengan jumlah sekitar satu juta spesies di seluruh dunia Karang adalah hewan tak bertulang belakang yang termasuk dalam Filum Coelenterata (hewan berongga) atau Cnidaria. Metode Transek photo bawah air (Underwater Photo Transect = UPT) merupakan metode yang memanfaatkan perkembangan teknologi, baik perkembangan teknologi kamera digital maupun teknologi piranti lunak komputer. Pengambilan data di lapangan berupa fotofoto bawah air yang dilakukan dengan pemotretan menggunakan kamera Canon G-16 yang dilengkapi pelindung tahan air (housing). Pada penelitian ini dapat dilihat persentase hard coral pada titik 1 berada dalam kategori sedang, titik 2 berada dalam kategori sedang, dan titik 3 berada dalam kategori buruk dengan persentase tutupan hard coral sebagai berikut: titik 1 (satu) 29,75\%, titik 2 (dua) 31,16\%, dan titik 3 (tiga) 24,26\%, dari ketiga titik dapat mewakili keseluruhan kondisi terumbu karang yang ada di Pantai Malalayang berada pada kondisi sedang dengan persentase $28,39 \%$.

Kata kunci: Pantai Malalayang, Terumbu Karang, UPT, CPCe 


\section{PENDAHULUAN}

Indonesia merupakan negara kepulauan yang terdiri dari 16.056 pulau dengan luas daratan $1.922 .570 \mathrm{~km}^{2}$ dan luas perairan $3.257 .483 \mathrm{~km}^{2}$ yang terletak di daerah Indo-Pasifik Barat (BIG, 2016). Indonesia yang berada dalam Kawasan Segitiga Terumbu Karang diakui sebagai salah satu negara dengan tingkat keanekaragaman karang yang tinggi, yaitu lebih dari 80 genus terdiri dan 596 spesies karang, khususnya di perairan Sulawesi bagian utara dimana di daerah ini dapat ditemukan lebih dari 80 genus (Suharsono, 2008 ; Giyanto et al., 2017).

Terumbu karang merupakan ekosistem pesisir dengan tingkat keanekaragaman tertinggi dengan jumlah sekitar satu juta spesies di seluruh dunia (Reaka-Kudla, 1997). Karang adalah hewan tak bertulang belakang yang termasuk dalam Filum Coelenterata (hewan berongga) atau Cnidaria. Terumbu Perumusan Masalah

Berdasarkan uraian latar belakang di atas adapun rumusan masalah pada penelitian ini adalah bagaimana kondisi terumbu karang di Pantai Malalayang?

\section{Tujuan Penelitian}

Adapun tujuan dari penelitian ini adalah :

1. Untuk mengetahui kondisi terumbu karang di Pantai Malalayang dengan menggunakan metode Underwater Photo Transect ( UPT )

karang ini bisa hidup lebih dari 300 jenis karang, yang terdiri dari sekitar 200 jenis ikan dan berpuluh-puluh jenis moluska, crustacean, sponge, alga, lamun dan biota lainnya (Dahuri, 2000).

Terumbu karang mempunyai fungsi yang sangat banyak bagi kehidupan ini baik dilihat dari aspek fisik ataupun dari aspek ekonomi. Peran fungsi terumbu karang bagi manusia kian hari semakin penting sehingga semakin bertambahnya nilai ekonomis maupun kebutuhan masyarakat akan sumberdaya yang ada di terumbu karang seperti ikan, udang

Ekosistem terumbu karang dikatakan buruk apabila mempunyai karang hidup sebesar 0 - 24,9\%, sedang apabila

\section{Latar Belakang}

merupakan hamparan tutupan karang dan merupakan kumpulan dari berjuta-juta hewan polip yang menghasilkan bahan kapur (CaCO3). Sedangkan terumbu karang adalah kumpulan dari berjuta-juta hewan polip yang menghasilkan zat kapur yang hidup di skeletonnya dan berkembang membentuk hamparan koloni yang luas (Thamrin, 2006). Terumbu karang dihuni berbagai macam biota laut yang merupakan sumber protein dari laut dan sumber bahan baku yang berguna dalam farmasi dan kedokteran. Terumbu karang juga merupakan ekosistem yang memiliki keindahan yang bernilai tinggi dan sangat potensial sebagai daya tarik pariwisata. Selain itu terumbu karang juga dikenal sebagai benteng alami yang berfungsi melindungi pulau dan pantai dari bahaya abrasi yang disebabkan oleh gempuran ombak.

2. Menyiapkan baseline data kondisi terumbu karang Pantai Malalayang

\section{TINJAUAN PUSTAKA}

\section{Ekosistem Terumbu Karang}

Ekosistem terumbu karang
merupakan bagian dari ekosistem laut
yang penting karena menjadi sumber
kehidupan bagi beraneka ragam biota laut.
Di dalam ekosistem terumbu lobster, tripang dan lain-lain, maka aktivitas yang mendorong masyarakat untuk memanfaatkan potensi tersebut semakin besar pula. Dengan demikian tekanan ekologis terhadap ekosistem terumbu karang juga akan semakin meningkat. Meningkatnya tekanan ini tentunya akan dapat mengancam keberadaan dan kelangsungan ekosistem terumbu karang dan biota yang hidup di dalamnya karena terumbu karang bisa menghasilkan 9 juta dari 75-100 juta ton hasil tangkapan ikan komersil dunia (Reid et al. 2011).

tutupan karang hidup 25 - 49,9\%, dikatakan baik apabila tutupan karang hidup 50 - 74,9\% dan dikatakan sangat 
baik apabila mempunyai tutupan karang hidup > 75 \% (KEPMEN LH. 2001).

\section{METODE PENELITIAN}

\section{Lokasi Penelitian}

Pengamatan kondisi terumbu karang di Pantai Malalayang ditetapkan 3 (tiga) Titik yaitu titik pertama berada pada titik koordinat $124^{\circ} 47^{\prime} 1,12^{\prime \prime} \mathrm{E}, 1^{\circ} 27^{\prime} 41.35^{\prime \prime} \mathrm{N}$ titik yang kedua berada pada titik koordinat $124^{\circ} 47^{\prime} 30,57^{\prime \prime} \mathrm{E}, 1^{\circ} 27^{\prime} 39.83^{\prime \prime} \mathrm{N}$ dan titik ketiga berada pada titik koordinat $124^{\circ} 47^{\prime} 18,83^{\prime \prime} \mathrm{E}, 1^{\circ} 27^{\prime} 47.48^{\prime \prime} \mathrm{N}$ seperti pada peta titik penelitian.

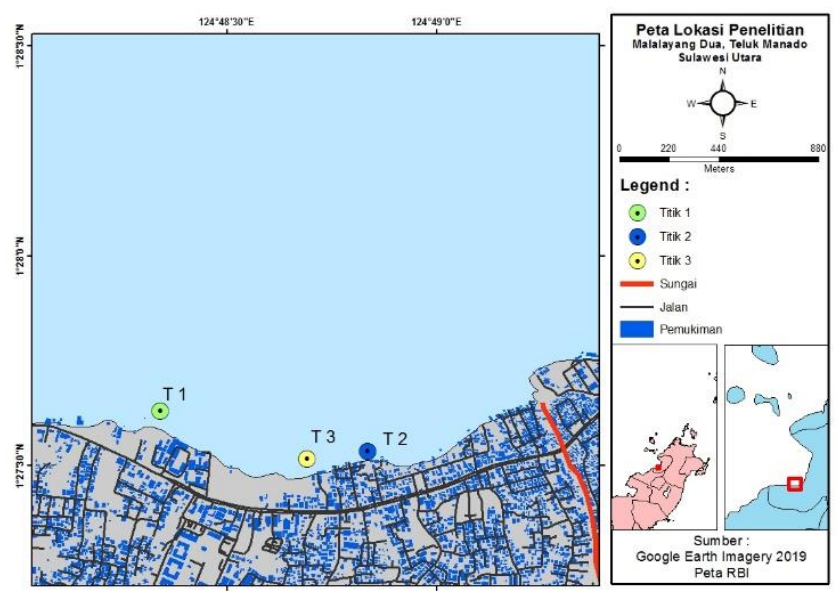

GAMBAR 1. Lokasi pengambilan sampel

\section{Teknik Pengambilan Data}

Metode Transek photo bawah air (Underwater Photo Transect $=$ UPT) merupakan metode yang memanfaatkan perkembangan teknologi, baik perkembangan teknologi kamera digital maupun teknologi piranti lunak komputer. Pengambilan data di lapangan berupa fotofoto bawah air yang dilakukan dengan pemotretan menggunakan kamera Canon G-16 yang dilengkapi pelindung tahan air (housing) (Giyanto, dkk. 2014). Tapi tidak harus juga mengunakan canon G-16 bisa juga mengunakan kamera lain yang memiliki kualitas atau resolusi gambar yang bagus atau besar, dimana dalam setiap lokasi akan ditarik garis 50 meter mengunakan roll meter, dan penelitian ini dilakukan pada tiga titik koordinat yang berbeda dimana setiap titik pengambilan data akan menghasilkan 50 foto karang yang di analisis dan total keseluruhan foto karang yang akan dianalisis berjumlah 150 foto. Foto-foto hasil pemotretan tersebut selanjutnya dianalisis menggunakan piranti lunak Coral Point Count with Excel extensions (CPCe) untuk mendapatkan data yang kuantitatif (Kohler dan Gill, 2006).

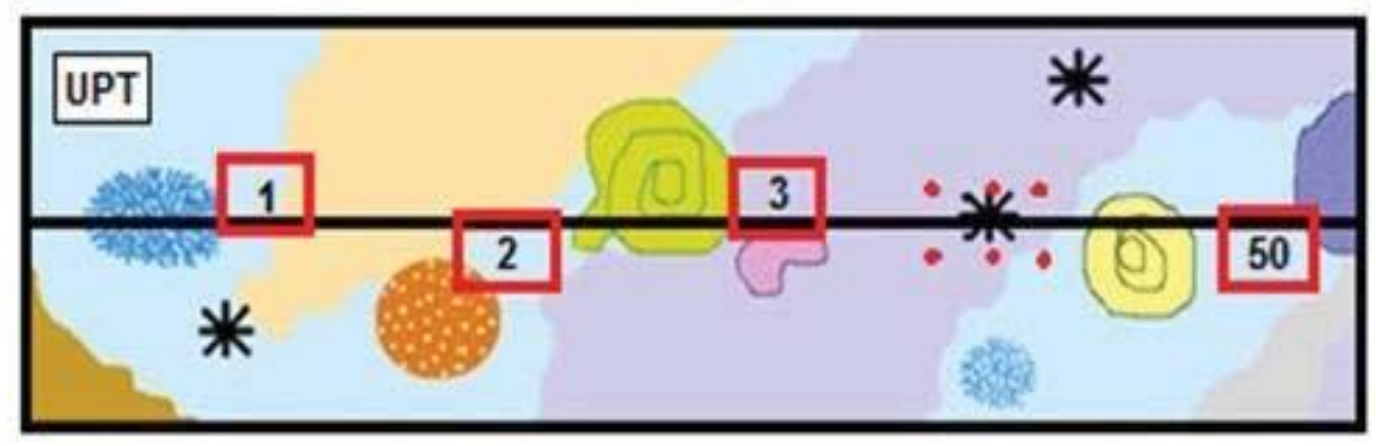

Gambar 2: llustrasi penarikan transek bawah air 


\section{Analisis Foto}

Data terumbu karang yang diambil dengan metode UPT merupakan foto-foto bawah air sebanyak 50 foto untuk setiap titik. Data perlu ditangani secara baik dengan cara segera memindahkan file-file yang masih tersimpan dalam memori kamera ke dalam media penyimpanan lain (external harddisk). Hal ini juga berguna untuk keamanan data.

acak yang digunakan adalah sebanyak 30 buah untuk setiap framenya, dan ini sudah representatif untuk menduga persentase tutupan kategori dan substrat (Giyanto, .2010). Teknik ini merupakan aplikasi dari penarikan sampel, dimana sebagai populasinya adalah titik-titik yang dipilih secara acak pada foto tersebut. Dengan cara ini, data yang dicatat hanyalah biota dan substrat yang berada
Analisis Data

Untuk mendapatkan data-data kuantitatif berdasarkan foto-foto bawah air yang dihasilkan dari motede UPT ini, analisis data dilakukan terhadap setiap frame dengan cara melakukan pemilihan sampel titik secara acak. Titik ini digunakan dengan menentukan banyaknya titik acak (random point) yang dipakai untuk menganalisis foto. Jumlah titik

tepat pada posisi titik yang telah ditentukan secara acak oleh piranti lunak CPCe.

Berdasarkan proses analisis foto yang dilakukan terhadap setiap frame foto yang dilakukan, maka dapat diperoleh nilai persentase tutupan kategori untuk setiap frame dihitung berdasarkan rumus sebagai berikut :

$$
\text { Persentase tutupan kategori }=\frac{(\text { jumlah titik kategori tersebut })}{\text { (banyaknya titik acak) }} \times 100
$$

Kondisi tutupan persentase terumbu karang selanjutnya dikategorikan berdasarkan pada baku mutu KepMen LH No. 4 tahun 2001 dengan kriteria seperti yang dapat dilihat pada Tabel 3.

Tabel 1. Persentase Tutupan Terumbu Karang

\section{HASIL DAN PEMBAHASAN}

\section{Kondisi Terumbu Karang Titik 1}

Dari hasil penelitian pada titik 1 ditemukan nilai persentase tutupan karang yang tertinggi adalah (S) sand 30,94\% (HC) hard coral 29,75\% (RK) rock 25,76\% (OT) other biota 5,98\% (R) rubble 4,38\% (SP) sponge $0,60 \%$. Persentase tutupan karang di titik 1 berada pada kategori sedang yaitu hard coral $29,75 \%$ dan persentase tertinggi di titik 1 adalah pasir dengan nilai 30,94\% ini dikarenakan struktur dasar perairan pada titik 1 Pantai

\begin{tabular}{|c|c|}
\hline Kondisi & Kategori \\
\hline Buruk & $0-24,9 \%$ \\
\hline Sedang & $25-49,9 \%$ \\
\hline Baik & $50-74,9 \%$ \\
\hline Sangat Baik & $>75 \%$ \\
\hline
\end{tabular}

Malalayang adalah pasir sehingga dapat mempengaruhi pertumbuhan dari terumbu karang di titik tersebut.

Berdasarkan data hasil analisis dimana 29,75\% Hard Coral ada 8 Hard Coral yang ditemukan yaitu : Acropora Encrusting, Acropora Submassive, Acropora Tabulate, Coral Branching, Coral Encrusting, Coral Foliose, Coral Massive, Coral Submassive dan yang paling dominan di titik ini adalah Coral Massive $14,48 \%$. 




Gambar 3. Persentase tutupan karang titik 1

Kondisi Terumbun Karang di Titik 2

Kondisi terumbu karang di titik 2 berada pada kategori sedang dimana persentase tutupan karang yang tertinggi adalah (HC) Hard Coral 31,16\% (RK) Rock $24,90 \%$ (S) Sand 18,37\% (OT) Other Biota $17,62 \%$ (SC) Soft Coral 3,74\% (R) Rubble $3,20 \%$ (SP) Sponge $0,61 \%$ dan (DCA) Dead Coral With Algae 0,41\%. Kondisi terumbu karang di titik 2 masuk dalam kategori sedang dengan persentase tutupan karang keras atau hard coral

Berdasarkan data hasil analisis dimana $31,16 \%$ hard coral ada 11 bentuk hard coral yang di temukan yaitu: Acropora Branching, Acropora Encrustin, Acropora Submassive, Acropora Tabulate, Coral sebesar $31,16 \%$ di karenakan struktur dasar Pantai Malalayang pada titik 2 tersebut merupakan batuan dimana substrat batuan tersebut merupakan substrat pendukung utama penancapan bagi terumbu karang (settle), persentase batuan sebesar $24,90 \%$ dan juga persentase pasir cukup tinggi dikarenakan tidak adanya ekosistem pendukung seperti ekosistem mangrove dan lamun sebagai penghalang masuknya sedimen dari darat melalui sungai menuju ke laut.

Branching, Coral Encrusting, Coral Foliose, Coral Massive, Coral Millepora, Coral Mashroom, Coral Submassive dan yang paling dominan pada titik 2 adalah Coral Millepora 16,94\%. 


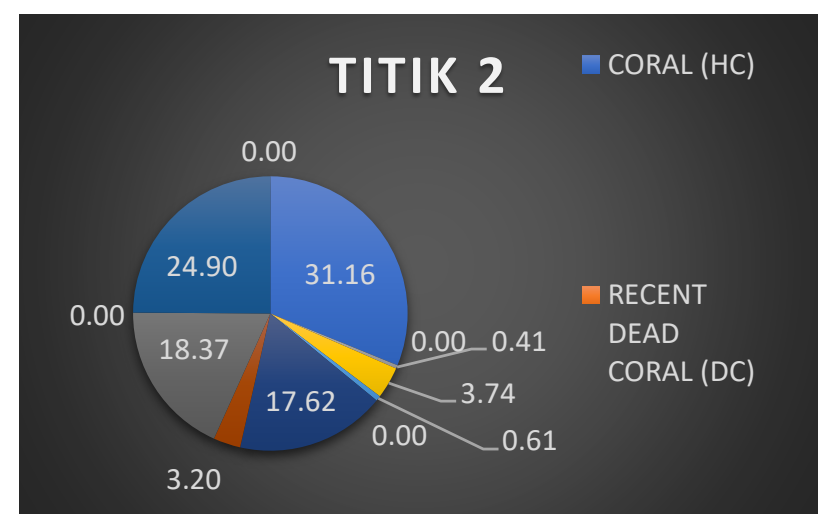

Gambar 4. Persentase Tutupan Karang Titik 2

\section{Kondisi Terumbu Karang Titik 3}

Kondisi terumbu karang pada titik 3 berada pada kategori buruk dengan persentase (HC) hard coral 24,26\% (S) sand $28,87 \%$ (RK) rock 22,06\% (OT) other biota $15,04 \%$ (SC) soft coral $4,54 \%$ (R) rubble $3,40 \%$ (SP) sponge 1,28\% (DCA) dead coral with algae $0,28 \%$ (FS) fleshy seaweed $0,28 \%$. Kondisi terumbu karang pada titik 3 Pantai Malalayang dikategorikan buruk yaitu $24,26 \%$ dan yang paling dominan di titik ini adalah pasir $28,87 \%$ dikarenakan struktur dasar perairan pada titik 3 ini adalah pasir seperti halnya pada titik 1 , sehingga sangat memperhambat pertumbuhan dari terumbu karang yang ada di perairan titik 3 Pantai Malalayang.

Berdasarkan data hasil analisis dimana 24,26\% hard coral ada 9 bentuk hard coral yang ditemukan yaitu: Acropora Branching, Acropora Encrusting, Coral Branching, Coral Encrusting, Coral Foliose, Coral Massive, Coral Millepora, Coral Mashroom, Coral Submassive dan yang paling dominan pada titik 3 adalah Coral Millepora 7,87\%.

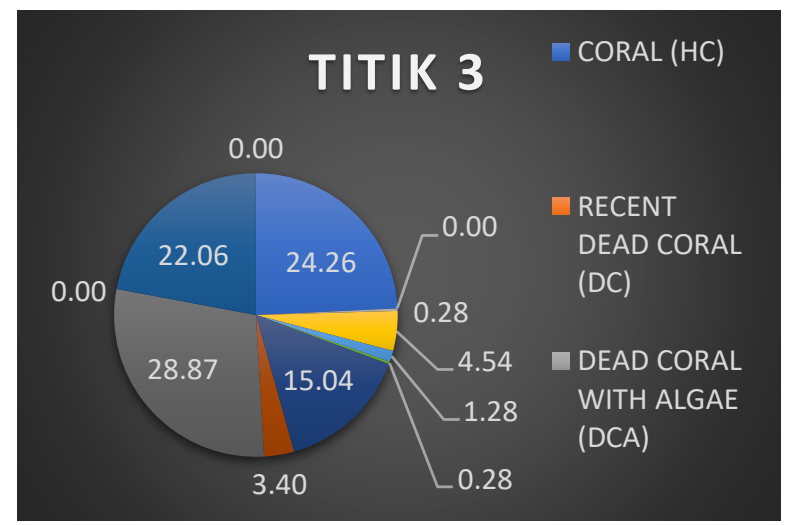

Gambar 5. Persentase Tutupan Karang Titik 3

Pada penelitian ini dapat dilihat persentase hard coral pada titik 1 berada dalam kategori sedang, titik 2 berada dalam kategori sedang, dan titik 3 berada dalam kategori buruk dengan persentase tutupan hard coral sebagai berikut: titik 1 (satu) $29,75 \%$, titik 2 (dua) $31,16 \%$, dan titik 3 (tiga) $24,26 \%$, dari ketiga titik dapat mewakili keseluruhan kondisi terumbu karang yang ada di Pantai Malalayang berada pada kondisi sedang dengan persentase $28,39 \%$. Untuk lebih jelasnya bias di lihat pada gambar 6 


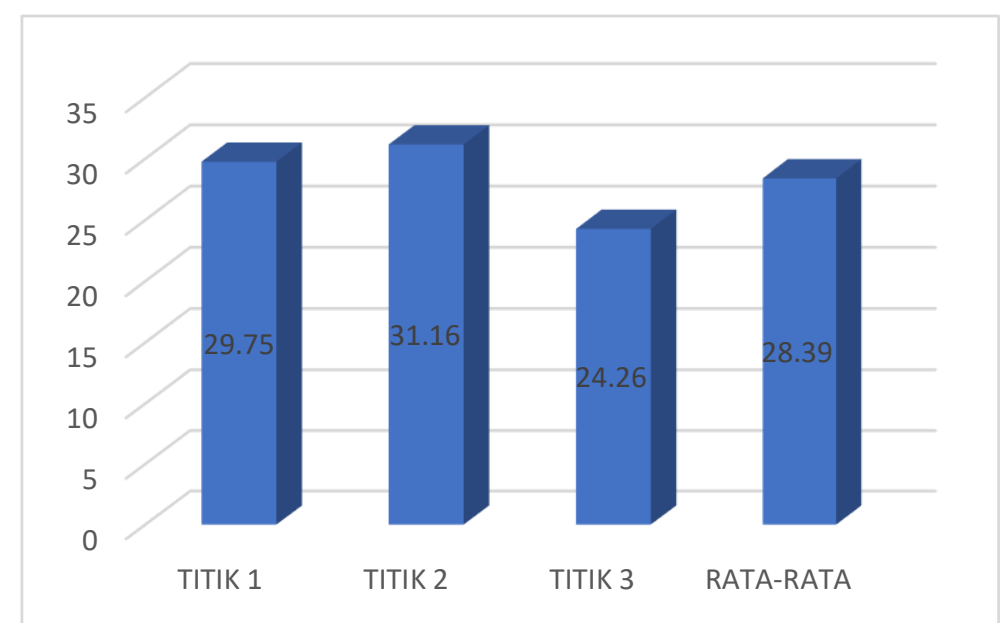

Gambar 6. Persentase hard coral di Pantai Malalayang

Data tutupan karang hidup dari ketiga titik diperoleh nilai rata-rata 28,39\% yang menunjukkan bahwa kondisi terumbu karang di Pantai Malalayang berada pada kondisi sedang. Jika dibandingkan dengan penelitian yang dilakukan oleh Schaduw et al. (2020) di Pulau Bunaken, Siladen, Nain, Manado Tua dan Mantehage menunjukan hasil persentase tutupan karang dari lima pulau ini dengan menggunakan metode yang sama adalah sebesar 32,92 \% hasil yang diperoleh menunjukan bahwa kelima pulau yang berada dalam kawasan Taman Nasional Bunaken memungkinkan pemantauan terhadap kondisi karang serta

\section{KESIMPULAN}

Dari pengamatan kondisi terumbu karang yang di lakukan pada 3 titik di Pantai Malalayang, persentase tutupan pada setiap titik tersebut berada pada kategori sedang. Jika di lihat kondisi terumbu karang dari setiap titik didapatkan titik 1 berada pada kategori sedang dengan

\section{DAFTAR PUSTAKA}

Bryant, D., L. Burke, J. Mc Manus, dan M. Spalding. 1998.Reefs at Risk: a Map-Based Indicator of Threats to the World's Coral Reefs. Cambridge: World Resources Institute. 56p.

Burke, L. dan M. Spalding. 2002. Terumbu karang yang terancam di Asia Tenggara. Terj. dari Reef at risk in pengelolaannya lebih terarah. Sehingga, masih perlunya dilakukan restorasi dan pengelolaan yang baik bagi terumbu karang di Pantai Malalayang.

Restorasi secara berkala dapat memulihkan kondisi terumbu karang di Pantai Malalayang sehingga terumbu karang di Pantai Malalayang berada pada kondisi baik mengingat Pantai Malalayang juga termasuk salah satu tempat wisata, dan juga termasuk salah satu lokasi snorkeling dan diving dengan demikian harus ada perbaikan pada Pantai Malalayang.

persentase $29,75 \%$, titik 2 berada pada kategori sedang dengan persentase $31,16 \%$, dan titik 3 berada pada kategori sedang dengan persentase $24,26 \%$, dari ketiga titik dapat mewakili keseluruhan kondisi terumbu karang yang ada di Pantai Malalayang berada pada kondisi sedang dengan persentase $28,39 \%$.

Southeast Asia. USA: World Resources Institute, USA. 67 hal.

Castro, J. dan T. Huber. 2007. Occurrence of polychlorinated dibenzo-pdioxins and dibenzofurans (PCDD/Fs), polychlorinated biphenyls (PCBs) and polybrominated diphenyl ethers (PBDEs) in Lake Maggiore (Italy and Switzerland) 
Castro, P dan Huber M. E. 2007. Marine Biology (Sixth Edition). McGraw-Hill Companies, Inc. New York. United States of America. p. 297-322.

Dahuri R, Rais J, Ginting SP, dan Sitepu MJ. 2001. Pengelolaan Sumber Daya Wilayah Pesisir dan Lautan Secara Terpadu. Jakarta: Pradnya Paramita.

Dahuri, R. 2000. Pendayagunaan Sumberdaya Kelautan untuk Kesejahteraan Rakyat. Lembaga Informasi dan Studi Pembangunan Indonesia (LISPI). Jakarta.

English, S., C. Wilkinson dan V. Baker. 1997. Survey Manual for Tropical Marine Resources. $2^{\text {nd }}$ Ed. ASEANAustralian Science Project: Living Costal Resources, Australian Institute of Marine Science. Townsville, Australia.

Giyanto, Muhammad Abrar, Tri Aryono Hadi, Agus Budiyanto, Muhammad Hafizt, Abdullah Salataholy, Marindah Yulia Iswari. 2017. Status Terumbu Karang Indonesia 2017. Pusat Penelitian Oseanografi-LIPI. Jakarta

Giyanto. 2010. Evaluasi Metode Transek Foto Bawah Air untuk Penilaian Kondisi Terumbu Karang. Disertasi. Institut Pertanian Bogor. Bogor.

Giyanto., A. EW Manuputty., M. Abrar., R. M Siringoringo., S. R Suharti., K. Wibowo., I. N E. U. Y. Arbi., H. A. W. Cappenberg., H. F. S. Y. Tuti. dan D. Zulfianita. 2014. Panduan Monitoring Kesehatan Terumbu Karang. Pusat Penelitian Oseanografi-LIPI. 77 hal.

Grevo S. Gerung, A.P. Harahap, A.B. Rondonuwu, H.K. Manengkey, I. Manembu, J.N.W. Schaduw, K.A. Roeroe, K. Kondoy, L.J.L. Lumingas, P. Makatipu dan W.E. Pelle. 2016. Monitoring Kesehatan Terumbu Karang dan Ekosistem Lainnya di Pulau Salwati dan P. Batanta, Kabupaten Raja Ampat.
Guntur. 2011. Ekologi Karang pada Terumbu Buatan. Ghalia Indonesia. Semarang.

Kase A. A. B, Manembu I. S, Schaduw J. N. W. 2019. Kondisi Terumbu Karang Pulau Mantehage Kabupaten Minahasa Utara Provinsi Sulawesi Utara.

KEPMEN LH. 2001. Keputusan Menteri negara Lingkungan Hidup no. 4 tahun 2001 tentang : Kriteria Baku Kerusakan Terumbu Karang. Menteri Negara Lingkungan Hidup Jakarta.

Kevin E. Kohler, S. M. (2006). Coral Point Count with excel extensions CPCe: A Visual Basic program for determination of coral and sibstrate coverage using random point count methodolgy. Computers \& Geosciences, 1259-1269.

Kusumastuti, A. 2004. Kajian Faktor-Faktor Penyebab Kerusakan Terumbu Karang di Perairan Bontang Kuala dan Alternatif Penanggulangannya.Tesis. Universitas Diponegoro. Semarang.

Phinn, S. R., C. M. Roelfsema. and P. J. Mumby. 2012. Multi Scale, ObjectBased Image Analysis for Mapping Geomorphic and Ecological Zones on Coral Reefs.International Journal of Remote Sensing. Vol 33(12). Hal 3768-3797.

PUSHIDROSAL. 2018. Data Kelautan yang Menjadi Rujukan Nasional Diluncurkan. Diakses tanggal 30 Juni 2020 pukul 18.10 WITA dari https://www.pushidrosal.id/berita/5 256/DATA-KELAUTAN-YANGMENJADI-RUJUKAN-NASIONAL-DILUNCURKAN/.

Reid, C., Justin Marshall, Dave Logan and Diana Kleine. 2009. Terumbu Karang dan Perubahan Iklim. Coral Watch, The University of Queensland. Australia. 256 hal. 
Roelfsema, Chris dan Stuart Phinn. 2010. Integrating field data with high spatial resolution multispectral satellite imagery for calibration and validation of coral reef benthic community maps. Jurnal of Applied Remote Sensing, Vol. 4,043527.

Schaduw, J.N.W., K.I.F. Kondoy, V.E.N. Manoppo, A. Luasunaung, J. Mudeng, W.E. Pelle, E.L.A. Ngangi, I.S. Manembu, N.S. Wantasen, D.A. Sumilat, N.D.C. Rumampuk, S.O. Tilaar, H.W.A. Manengkey, R. Lintang, J.Y. Walalangi, B. Tampanguma, F. Pungus, Y.Lahabu, B. Sagai, E. Wantah, L.L. Wantania, B. Djabar, A.P. Oli, E.A. Caroles, F. Bachmid, J. Sasauw, A. Kase, A. Anthoni, A.D. Uada, R. Ladjandu, C. Coloay, S. Kojongian, N.N.T. Mamangkey. 2020. Data On Percentage Coral Reef Cover In
Small Islands Bunaken National Park. Data in Brief, 31, 105713.

Suharsono. 2008. Jenis-jenis Karang di Indonesia. Lembaga IImu Pengetahuan (LIPI) : COREMAP Program. Jakarta

Supriharyono. 2000. Pelestarian dan Pengelolaan Sumber Daya Alam di Wilayah Pesisir Tropis. Gramedia Pustaka. Jakarta.

Suwigyono, S., Widigdo B, Wardiatno Y dan Kristanti M. 2005. Avertebrata Air. Penebar Swadaya. Jakarta.

Thamrin. 2006. Karang: Biologi Reproduksi dan Ekologi. Minamandiri Press. Pekanbaru.

Tomascik, T., A. J. Mah., A. Nontji. and M. K. Moosa. 1997. The Ecologi Of The Indonesian Seas. Part I. Singapore: Periplus Editions. 